\title{
Internalising Engineering Education in Africa
}

\author{
Dr. Kehdinga George Fomunyam \\ Teaching and Learning Development Center, Mangosuthu University of Technology, Durban, South Africa.
}

\begin{abstract}
The education system in Africa is generally deficient and fraught with challenges, and engineering education is not left out. For Africa to achieve economic growth and development, many of its fundamental problems have to be addressed, including those plaguing the education sector. Additionally, the concepts, pedagogy, ideology and methodologies inherent in engineering education in Africa have to be revised and realigned with the developmental needs and goals of African countries. Elements of Africa's ideologies, concepts and culture have to be incorporated into the engineering curriculum for easier assimilation and practical application. This study assesses the current situation inherent in engineering education in Africa, recommends solutions to some of the conceptual, structural and functional problems of engineering education and suggests ways of effectively internalising engineering education across Africa.
\end{abstract}

Keywords: Internalising, Engineering Education, Engineering

\section{INTRODUCTION}

Engineers are key to the technological development of a country, therefore it is of paramount importance that sufficient, continuous and relevant training be made available to students of engineering to equip them with the skills they require to be initiators and implementers of technological innovation and development ( Falade, 2016). Engineering can still be considered to be at an embryonic stage in the majority of African countries. This is so because a lot of the tools needed to impact knowledge in different subjects related to STEM are absent in the often deficient educational system in Africa (Barakabitze, 2019). Faulty educational foundations and capacity deficiencies are a major part of Africa's challenge in successfully transforming its economy. In order for engineering education to be impactful to the African economy, it has to be adapted to the economic system and technological needs of Africa and this can only occur through internalization.

The initial process starts with understanding the core concepts, principles and ideologies of engineering and customizing or personalizing them to Africa's innovative, design and structural goals and needs. Engineering education has to be conceptualized, interpreted and incorporated into Africa's educational system and curriculum in a way that is relevant to and addresses Africa's development objectives. This process of internalization starts with learning what the norms are and then the individual goes through a process of understanding why they are of value or why they make sense. In the case of engineering education mastering and understanding the fundamental skills, concepts and intricacies of engineering is an integral part of solving many of Africa's technological and economic problems and joining the industrial growth trend evident in developed countries. Consequently, African governments are recognising the importance of promoting engineering education alongside other STEM subjects across all levels of educational institutions.

What would stimulate engineering and technological innovation in Africa and what would be required to bridge the gap between nations in terms of educational and developmental inequality? This study explores the inefficiencies and gaps in engineering education in Africa especially as concerns the structure of the educational system, curriculum contents and deficiencies, teaching and learning methods, available supplementary resources and also its research and experimentation methods for the purpose of creating an enabling environment for students, academics and professionals to internalize engineering content in a way that would place the continent on the path of innovation and economic growth.

\section{UNRAVELLING THE DYNAMICS OF ENGINEERING EDUCATION IN AFRICA}

In discussing its internalization, one must first answer the question; what is the role of engineering education in Africa? Engineering involves the application of scientific and mathematical principles and judgement for the benefit of mankind. Engineering makes processes easier and more convenient through the use of scientific, mathematical and technical knowledge which provides understanding on the creation and workings of innovation, design, development, invention and the application of structures, processes, materials, systems and machinery for specified purposes (Martin, 2018). Zeiteh (2002) posits that the majority of engineering programs in Africa were designed by the colonialists who imposed an education system and curriculum not tailored to suit the continents needs but mirrored the system and ideologies of the western world after which it was patterned. Many African countries still operate colonial education systems and are still currently and gradually dismantling this system in favour of a more representative one. Consequently, over the years academicians have continuously called for the decolonization of higher education in Africa (Fomunyam, 2017). 
According to Falade (2016), focus of engineering education in Africa should be on initiatives vital to restructuring the educational system and promoting appropriate and effective teaching methodologies and learning techniques, updated and appropriate itinerant curriculum, proper accreditation process, good practice in academic staff recruitment and training, standard and uniform admission criteria and good universityindustry partnership geared towards fostering consistent student internship, mentorship and training programmes. The opportunity for private funding of research and experimentation is also one of the perks of a good relationship between tech industries and higher institution. Professional body accredited, regulated qualifying professional exams and continuing education programmes for graduate engineers are also essential (Falade, 2016). The Harvard Graduate School of Education (2016) posits that personalized learning involves shifting teacher practice and encouraging students to take greater ownership of their learning, while building their leadership, collaboration, and problem-solving skills.

A 2005 report by the National Academy of Engineering, on how to educate the engineers of 2020 opines that engineering education must be adapted to the issues of globalization. "What" is to be learnt and the reason why those target outcomes are needed must adequately address and align with course and curriculum redesign. Strategies for achieving the set goals must also be well outlined (Mistree et al, 2014). The competencies required of a successful engineer today and in the future are different from those needed in the past because the nature of innovation is changing and ideas and competencies are now required for innovative goals to be actualised. Engineers now face the universal challenge of managing issues among social, economic, ecological, and intellectual capital (Hawthorne et al., 2012) (Bertus et al., 2012) (Ahmed et al., 2012). Future engineers will need to possess competencies that support innovations beyond the current models which are often limited to economic considerations. Future innovators will also need to be equipped with more than just skills in their specialties (Christensen \& Raynor, 2003) (Warnick, 2011) (Downey et al., 2006). To encourage innovation personalized learning environments have to be created within classrooms where each individual can focus on different competencies while working in a group.

According to Shizha (2014) cognitively, past knowledge, cultural values, and historical happenings should form the roots of African curriculum. Indigenous voices provide African students with the cultural capital they need to improve their capacity for meaningful learning, better school performance and educational achievements. African governments should choose school knowledge based on the local cultural capital that is relevant and appropriate to their citizens. How knowledge is created, validated and disseminated is vital to students' cognition and their abilities to acquire knowledge and make use of that knowledge. The schooling model in Africa presently, is extremely structured and limits the freedom of both teachers and students. Western education focuses on abstract knowledge that does not correspond to the views of African students. One of the key steps to internalization is attained from implementing African indigenous knowledge in school curricular that mirror the actual cultural needs and expectations of communities in which the schools are located. Meaningful learning should be embedded in community livedexperiences of the African learners. Students rely on their personal knowledge and their community knowledge and lived situations to reflect on their learning experiences and the teachers' pedagogical interactions with students (Freire, 1998). Thus, students better process information that has practical significance. In other words, engineering education will be better internalized if there is a shift from the predominantly theoretical curriculum and teaching methodology to more practical and relatable learning that is flexible enough for the inclusion of personalized learning tools.

\section{EVALUATING THE CURRENT STATE OF ENGINEERING EDUCATION IN AFRICA}

Research by the African Development Bank has shown that most African schools do not specialize in STEM subjects and less than $25 \%$ of African tertiary institution students are in STEM fields, with the majority of students studying social sciences and humanities. A study carried out by the Royal Academy of Engineering concluded that engineering academic staff in tertiary institutions in SSA "had very little exposure to engineering practice [in industries and public works]" despite being well-qualified. The teaching methods in the majority of the higher institutions in the region was summed up as "chalk and talk" as opposed to problem-based learning (PBL). In 2014 another study by the Inter-University Council for East Africa, reported that in Uganda about $63 \%$ of university graduates were not equipped with job market skills-Tanzania, 61\%; Burundi, 55\%; Rwanda, 52\%; and Kenya, 51\% (Nganga, 2014).

Uwaifo (2009), posits that "a country is said to have a setback in engineering education when the products from (its) engineering institutions cannot produce capital goods such as tractors, lathe machine, electrical \& electronics devices, drilling machines, cars, iron and steel, train and other earth moving equipment as well as being unable to provide the engineering skills and expertise to undertake the exploitation of her natural resources". This is the norm in the majority of African countries where the quality of engineering education available fails to empower graduates with the necessary knowledge and skills needed to undertake even the most elementary level of manufacturing or innovation. Mukeredzi (2019) opines that Africa has a critical shortage of highly trained engineers and low enrolment in STEM programmes, far behind global averages. Specifically, the African Capacity Building Foundation has estimated the continent suffers from a shortage of over four million engineers. According to Kigali (2019), there are fewer than 2,000 colleges and universities on a continent with a billion people in 55 countries with less than $7 \%$ of Africans possessing college degrees.

Extensive research by scholars across the continent has determined the situation of engineering education and training in Africa to be critical and Goolam (2014) attributes this state of affairs to; A shortage of engineers yet unemployment of engineering graduates in some African countries, limited funds to procure laboratory equipment and other facilities, obsolete curricula and old methods of teaching as well as poorly educated graduates who are sometimes unemployable and 
unable to compete with foreign trained colleagues, poorly qualified academic staff with limited industrial experience. Other issues range from the adoption of traditional pedagogy linked to curriculum epistemicide to poor funding as a result of low government allocation to the education sector and limited private support for higher institutions. Some other problems are; weak collaboration with international engineering community, inadequate ICT and structural facilities, insufficient training and research equipment and human capital resulting from poorly qualified academic staff, low staff retention rate and brain drain, accreditation inconsistencies across engineering institutions, predominantly theoretical learning with limited practical application for students are also challenges faced, as are Inadequate research and experimentation.

Lawless (2005) ascribes the current state of engineering education in Africa to; difficulty in recruiting and retaining staff because of poor employment conditions, weak universityindustry partnership, limited opportunities for industrial experience for engineering students. The low capacity is attributable to a number of reasons including; limited public investment in engineering infrastructure projects, inadequate legislation to uphold engineering standards through requirements for professional registration, lack of regulatory laws to enforce foreign companies to effect knowledge transfer to local engineers and other issues, all resulting in brain drain of engineering talent to other sectors or other countries.

While engineering has been introduced in the education system in most African countries the expansion and its adoption remains slow due to a lack of effective education policies, teacher capacity, and financial resources (Barakabitze, 2019). Engineering education impacts growth and development in various sectors of any economy. Economic and structural stagnation as well as increased rate of failure in engineering infrastructure in Africa makes it imperative that Africa adapts and incorporates engineering ideologies to its particular system thereby improving the quality of engineering education obtainable in Africa. This will also facilitate identifying Africa's engineering capacity needs and promote innovation and engineering solutions that directly address Africa's particular fundamental, foundational and structural challenges.

\section{A CASE FOR INTERNALIZING ENGINEERING EDUCATION IN AFRICA}

The Oxford American Dictionary defines internalization as making (attitudes or behaviour) part of one's nature by learning or unconscious assimilation. Through internalization individuals accept a set of norms and values that are established by other individuals, groups, or society as a whole. The initial phase of internalization involves learning what the norms are, and then understanding why they are valuable or why they make sense, then comes acceptance of the norm as their own point of view. Internalised norms usually become part of an individual's personality. Internalization in engineering education implies adapting and personalizing the educational system and curriculum inherited from the colonialists to suit the technological needs in African countries. The systems, processes and procedures that make up engineering education would be moulded by the government and institutions to be relatable to the students and encourage assimilation in a way that fosters relevant research, experimentation, invention, innovation and overall technological development. Internalization of engineering education in Africa would require commitment from the government, the private sector and higher institutions. According to Falade (2016), engineering education concerns two principal facets of education namely, teachers and the students, that is, the instructors and the future practitioners of engineering. The students and academic staff play a major role in how engineering is taught and assimilated in Africa. Methods that enhance learning activities in a classroom are based on mental models, personal mastery, systems thinking, a shared vision, and team learning (Siddique, Panchal, Schaefer, Allen, \& Mistree, 2012). (Hawthorne, Sha, Panchal, \& Mistree, 2012): This involves shifting the role of the instructor to become a facilitator of learning who creates opportunities for students to learn and also a shift in the role of students to become active learners who play a significant role in the learning process. They define their own learning goals and are responsible for directing their efforts to achieve their goals. Students are also presented with a variety of decision making methods and tools and students are given opportunities to make decision and evaluate the consequences (Mistree, 2012). Virtual collaborations, online group study classes and projects, self and peer assessments and reflective practice (Mistree et al, 2014). Apart from teaching and learning methods, other areas where changes need to occur are; in research and experimentation techniques, curriculum, government policies and the level of government-industry-higher institution collaboration.

The MDPI, Multidisciplinary Digital Publishing Institute (2019) postulates that dismantling the colonial education system predominantly practiced across African countries, especially the curriculum is a key part of achieving engineering education excellence in Africa, as a non-representative curriculum and education system cannot be moulded to suit indigenous conditions and needs in terms of systems, structures, functions and innovation. A deterritorialized curriculum combining relevant western and indigenous elements needs to be adopted for internalization to be possible. An itinerant curriculum where African content is engrained into every aspect of engineering will most likely deliver structures and innovations that will bridge the infrastructural gaps evident throughout Africa. Problem-based learning methods suited to the needs of engineering education in Africa have to be adopted (MDPI, Multidisciplinary Digital Publishing Institute, 2019). Training programmes crafted to upgrade teachers competence and skills while equipping students with knowledge and skills tailored to indigenous goals of innovation and economic development are equally important.

A huge part of addressing majority of the problems hindering engineering education outlined above and stimulating economic growth and innovation through the provision of quality education would entail internalizing engineering education and making a paradigm shift away from the epistemic teaching methods and ideologies still in practice in African higher institutions which were handed down by 
western colonialists. Economic advancement would continue to be slow and almost evasive in Africa if the curriculum epistemicide is not addressed, as education is a key instrument of change and one of the major foundations of any society. Transformation and growth would require an overhaul of the current educational system. Without the knowledge imparted by a balanced education system where knowledge assimilation is aided by incorporating indigenous elements, the human capital charged with spearheading change would be severely handicapped as the fundamental and expert knowledge needed to carry out tasks, from the most elementary to complex innovative processes would be lacking.

The complexities inherent in any society affects its education system. Economic, political and environmental issues are just some of the areas that impact engineering education in Africa. Environmental issues include pollution resulting from the rapid growth of cities in major African states which increases air pollution from toxic gas emissions and industrial waste which pollutes water bodies. Oil spill from extraction activities kill marine life and increase air pollution as well. Africa's economy is mostly dependent on oil and agriculture, which employs a large percentage of the population and contributes heavily to GDP and exporting raw materials and farm produce. With national debts to be resolved and pest outbreaks reducing agricultural output across Africa, internalizing engineering education can bridge the gap and provide an alternative means of income if infrastructure and all necessary tools are available to higher institutions for research and potentially innovation of new systems and upgrading of existing systems and structures across all sectors ranging from agriculture, to technology, transportation, manufacturing and telecommunication across Africa. Conversely, economic and especially political policies can affect government and private sector participation in advocating for and funding favourable educational policies that will ensure effective internalization of engineering education in African countries. Theoretical learning is emphasized much more than practical application in Africa, while advocating for the adoption of a more practical approach, these theories should be streamlined to include aspects of engineering education peculiar to the African economic and political system especially as relates to technology innovation, manufacturing, trade, service delivery, and agriculture. Systems adaptability, creativity, and efficiency should be emphasized in theory and practice when teaching students of engineering. The emergence of the fourth industrial revolution characterized by the merging of digital, biological, and physical technologies as well as the growing utilization of new technologies such as robotics, Artificial Intelligence, cloud computing, 3D printing, the Internet of Things, and advanced wireless technologies, among others, provides a potentially tremendous opportunity for socio-economic growth in Africa as well. These technologies provide an opportunity for Africa to maximise its agricultural potential as well as build up its manufacturing sector while improving income, demand, sales and distribution. Sufficient infrastructure development will drive and sustain economic transformation in Africa. Lower transport and communication costs will then enable countries with suitable agro-ecological conditions produce high-value products. Bridging the internet connectivity and access gap with advanced economies will allow more African countries enter the service export markets. Small-scale manufacturers with access to digital platforms for research, sales, and distribution will become more competitive as well. For these changes to occur Africa's educational system needs to be upgraded to sufficiently handle ongoing change. Universities and engineering academia should be empowered to shape and equip students with tools to be relevant in the ongoing revolution. They should also collaborate with private organisations to identify employers needs which would be translated into academic programs aligned to the current needs of Africa and the world. Policy changes need to be initiated to drive this educational reform. It is believed that engineering will build the 4th Engineering Revolution even as engineering itself evolves.

According to Bates and Leary, (2001) students must be given access to the most appropriate tools and environments that present information in an engaging manner and also provided with appropriate support for the diversity of individual student learning styles". "Learning styles," are the result of educational experience, and cultural background. In order to facilitate academic success, it is important to provide learning experiences that are accessible to all students with all learning preferences. Learning styles" (LS) can help to guide students to the study techniques that are most likely to be effective to them. It can give an indication on how students can respond to different types of lecture delivery and consequently if they like to approach new material. To get the best results education has to adapt to the needs of the learner. Students may like to work in small groups, while some may prefer to work individually. On the instructor's side, (LS) can be used to help in enhancing and improving the lecture presentations. An instructional strategy with a particular learning style can work for students with a similar learning style but cause problems for others with a different way of studying the same material (Chamillard and Ricky, 2005).

Kunnath (2019) advocates the use of course-building Templates with multimodal techniques like Augmented Reality, Virtual Reality and Simulation to make learning more effective. Engineering faculties should also take advantage of emerging trends in technology-driven teaching with the rising popularity of AI and deep learning. Faculties must recognize learner styles, learner abilities, comprehension and understanding in Artificial Intelligence (AI) as it enhances digital intelligence in almost all aspects of our personal lives. Topics that support personalized teaching and learning using technology to make it more effective, efficient and pragmatic should be adopted. The recent shift to a virtualized higher education especially with the adoption of AI, makes it imperative for faculty and instructors to take on the role of programmers and builders of their courses which must be regularly updated. Educational technology tools like deep learning, machine Learning, big data, Internet of Things (IoT), and artificial intelligence brought about the switch from passive to active learning allowing students define their knowledge accumulation, construction, and learning pathways. Innovation and adaptation are slowly chipping away the traditional 
education system and faculties must assume leadership roles to make the switch to technology-aided teaching and learning easier. They must take on new tasks like designing robotized courses through aggregating and updating content, that is, building virtual robot assistants, programming robots consciousness and automated pulling of content from a variety of resources. While debates and experimentation continue to grow in artificial intelligence and industry-driven automationdriven AI persistently seeks out areas to automate and simplify, technology continues to blend academic and practical real world experience. The corporate industry has an impact on trends in tertiary education as they are able to provide insight into real world challenges and propose direction of research and experimentation (Kunnath, 2019).

Mistree et al, (2014) posits that a shift in focus from the lower levels to the upper levels of learning is required. This involves less focus on knowledge of core concepts and their application to technical systems, namely, competencies to higher focus on gaining the abilities to analyse, synthesize and evaluate. Course flexibility is required by having guest lectures on diverse topics, asking the students to define their own goals and letting the students adapt various parts of the course to suit their learning needs. This includes adding discussion sessions, selfstudy time, virtual collaboration, providing the opportunity to create new knowledge with a collaborative group project, reflective practice, and self and peer evaluation.

A 2005 report by the National Academy of Engineering, on how to educate the engineers of 2020 posits that engineering education must be adapted to the issues of globalization. The educational content and goals must adequately address and align with course and curriculum redesign. Strategies for achieving the set goals must also be well outlined. The nature of new challenges will require them to take on open-ended illdefined problems and unforeseen issues, understand system level challenges, address them with creative thinking, and respond to them with innovations. If they have not experienced creative that require innovative responses in their engineering classes, they will not be prepared to do so in their professional careers. They are expected to tackle poorly defined system level challenges and unanticipated problems and respond to them by innovating solutions. They have to handle various challenges in training or class to be equipped to face them in reality so content they are exposed to and absorb in class plays a vital role in shaping the quality of engineers they become. These changes are applicable to engineering education in Africa as well. To properly assimilate and translate knowledge gained to invention and innovation, several changes must occur and be embraced at various levels of education in Africa. Children must be introduced to STEM subjects at an early age in a way that stimulates their minds and encourages them to explore the basic concepts of these subjects. At a tertiary level, a variety of teaching and learning techniques must be presented with the goal of students pursuing learning methods most suitable for them. Technology must be embraced and incorporated into teaching techniques by the instructors who must take on new roles as programmers and facilitators of digital learning. Personalized online courses should be explored as well as convenient and modern educational tools that are created with due consideration of a country's indigenous needs and goals. These tools must also be built to facilitate individual learning. A strong educational foundation must be laid that can produce qualified academicians thoroughly equipped with good knowledge and tools to educate the younger generation of engineers. Also the problem of brain drain where African countries lose brilliant minds to other countries must be addressed. Engineering curriculums should be adjusted every semester to reflect indigenous content presented in a manner that both aligns with a country's infrastructural development objectives and also reflects its cultural and economic foundation.

\section{METHODOLOGY}

The research methodology is based on a literature review of descriptive information. This study utilized a qualitative data collection technique by reviewing and drawing information from various papers and articles published between 1998-2019 to examine the state of engineering education in Africa. The study examined 37 published works authored by education experts and adopted a descriptive methodology to review these journals and papers in the course of articulating how engineering education can be internalized in Africa. These papers were sourced through an internet search utilizing some keywords. The search terms used are; internalizing OR personalizing OR engineering OR engineering education.

\section{FINDINGS}

This study established that the state of engineering education in Africa is below par and way behind its western counterparts in terms of embracing technology and incorporating it into everyday pedagogy as a means of making teaching and learning methods easier and more personal. Building an itinerant curriculum with heavy emphasis on an indigenous method of teaching and learning and also embracing a less Westerncentric education system will help address the epistemicide in Africa's educational system. Also curbing brain drain and Embracing specialized online courses will aid assimilation, retention and relatability for students. The study examined computerized educational resources available and how they can be customized to align with Africa's educational objectives.

\section{CONCLUSION}

Incorporating engineering education into the very fabric of Africa's economy is synonymous with achieving its developmental goals. Innovation and invention is a key part of Africa's economic growth and such growth will be impossible without locally-focused, intrinsic teaching and learning methods, research, experimentation and innovation of engineering and technological systems and structures. The knowledge needed to achieve this has to be inherent, personalized, delivered and assimilated effectively for the human capital to be able to take on a productive role, thus 
International Journal of Engineering Research and Technology. ISSN 0974-3154, Volume 13, Number 9 (2020), pp. 2429-2436

(C) International Research Publication House. https://dx.doi.org/10.37624/IJERT/13.9.2020.2429-2436

internalization of engineering education is key to Africa's overall welfare and advancement.

\section{RECOMMENDATION}

To properly internalize engineering education governments across Africa have to focus on encouraging youngsters to embrace STEM subjects from an early age by creating programmes and tools that allows them explore and familiarize themselves early on with the rudiments of research, data collection and analysis, experimentation and diverse learning methods. Personalized learning environments should be created within classrooms where each individual can focus on competencies of their choice. Africa's predominantly Westerncentric curriculum has to be reformed, governments and the private sector, especially the tech industry has to partner with higher institutions to augment efforts towards incorporating indigenous and relatable elements into the curriculum. Policy reforms are also necessary with focus on promoting and engraining elements of digital learning techniques into the educational system. Teachers have to be willing to take on new roles as digital learning facilitators guiding students through learning. A shift in focus from theoretical learning to more advanced levels of personalized, practical teaching and learning techniques are required. Students should be encouraged to define their goals and customize aspects of courses to align with their learning needs and enable them gain the abilities to analyse, synthesize and evaluate information.

This entails a shift in emphasis from conceptual knowledge and their application to technical systems, namely, competencies to higher focus on gaining the abilities to analyse, synthesize and evaluate. Course flexibility is required by having guest lectures on diverse topics, asking the students to define their own goals and letting the students adapt various parts of the course to suit their learning needs. This includes adding discussion sessions, self-study time, virtual collaboration, providing the opportunity to create new knowledge with a collaborative group project, reflective practice, and self and peer evaluation (Mistree et al, 2014). MOOC courses are good resources for personalized learning as they offer learning resources for students to prefamiliarize themselves with courses before hand. African higher institutions and engineering faculties in particular need to embrace Massive Open Online Courses (MOOCs) such as EdX which offers courses to universities, Coursera and Udacity both run courses for corporations while Open CourseWare $(\mathrm{OCW})$, and hybrid designs offer free courses for developing countries.

\section{CONTRIBUTION OF NEW KNOWLEDGE}

African universities should explore the use of AI as a means of encouraging adaptive learning techniques by designing and developing customized courses that offer individualized attention to each student. The use of virtual assistants programmed to build online courses for instructors and students based on individual teaching and learning styles. A studentfocused application which assembles engineering curriculums on the same course from universities all over the world and allows students personalize their learning experience by choosing their preferred course program of study.

\section{REFERENCES}

[1] Ahmed, N., Chetty, R., Mobarak, M., Rahman, A., Singal, M. (2012). Improving Tax Compliance in Developing countries: Evidence from Bangladesh. Retrieved from: https://www.theigc.org/wpcontent/uploads/2014/10/Ahmed-et-al-2012-WorkingPaper.pdf

[2] Andrews, J., Knowles, G., Clark, R. (2019). Excellence for Engineering Education for the $21^{\text {st }}$ Century: The Role of Engineering Education Research. Retrieved from:https://warwick.ac.uk/fac/sci/wmg/mediacentre/w mgevents/eern/proceedings_13_dec.pdf

[3] Barakabitze et al (2019) Transforming African Education Systems in Science, Technology, Engineering, and Mathematics (STEM) Using ICTs: Challenges and Opportunities. Retrieved from: https://www.hindawi.com/journals/edri/2019/6946809/

[4] Bates, B., Leary, J. (2001). Supporting a range of learning styles using a taxonomy-based design framework approach. Proceedings of the Annual Conference of Australian Society for Computers in Learning and Tertiary Education. Retrieved from: http://www.ascilite.org.au/conferences/melbourne01/pd f/papers/batesb.pdf

[5] Warnick, B., Silverman, S., (2011). A Framework for Professional Ethics Courses in Teacher Education. Retrieved from: https://journals.sagepub.com/doi/ 10.1177/0022487110398002

[6] Chamillard, A., Sward, R. (2005). Learning styles across the curriculum. Retrieved from: https://www.researchgate.net/publication/220807153_L earning_styles_across_the_curriculum/citation/downloa d

[7] Christensen, C., Raynor , M. (2003). The Innovator's Solution: Creating and Sustaining Successful Growth. Boston: Harvard Business School Press. Retrieved from https://www.hbs.edu/faculty/Pages/item.aspx?num=154 73

[8] Downey, L., Mountstephen, J., Lloyd, J., Hansen, K. (2011). Emotional intelligence and scholastic achievement in Australian adolescents. Retrieved from: https://www.researchgate.net/publication/229996664_E motional_intelligence_and_scholastic_achievement_in _Australian_adolescents

[9] Edstrom, K (2016). Academic and Professional Values in Engineering Education: Engaging with History to Explore a Persistent Tension. Retrieved from: https://www.tandfonline.com/doi/full/10.1080/1937862 
International Journal of Engineering Research and Technology. ISSN 0974-3154, Volume 13, Number 9 (2020), pp. 2429-2436

(C) International Research Publication House. https://dx.doi.org/10.37624/IJERT/13.9.2020.2429-2436

\subsection{8 .1424860}

[10] Enoch, J (2020). Nigeria and the Fourth Industrial Revolution. Retrieved from: https://www.tekedia.com/ nigeria-and-the-fourth-industrial-revolution/

[11] Falade, F. (2016). Advancement of Engineering Education in Africa: AEEA Perspective. Retrieved from: http://www.ifees.net/dvancement-of-engineeringeducation-in-africa-aeea-perspective/

[12] Fasihuddin, H., Skinner, G., Athauda, R. (2014). Personalizing open learning environments through the adaptation to learning styles. Retrieved from: https://scholar.google.com/scholar?q=personalizing+en gineering+education $\& \mathrm{hl}=\mathrm{en} \&$ as_sdt=0\&as_vis $=1 \&$ oi $=$ scholart\#d=gs_qabs\&u=\%23p\%3DgZYa0GGCVq8J

[13] Fataar, A. (2016) Towards a Humanising Pedagogy through an Engagement with the Social-Subjective in Educational Theorising in South Africa. Retrieved from:https://www.google.com/url?q=https://pdfs.seman ticscholar.org/fd4f/7008736abe4977f84acdd0797ea432 695061.pdf\&sa=U\&ved=2ahUKEwiB19fB0uLqAhUC XRoKHdkvCjkQFjABegQIBxAB\&usg=AOvVaw3HP MwanjkIkrn942oYwQVX

[14] Fomunyam, K. (2019). The Political Dimensions of Engineering Education in Africa. International Journal of Mechanical Engineering and Technology 10(10), 2019, pp. 196-205. Retrieved from: http://www.iaeme.com/IJMET/issues.asp?JType=IJME $\mathrm{T} \&$ VType $=10 \&$ IType $=10$

[15] Freire, P. (1998) Pedagogy of Freedom: Ethics, Democracy, and Civic Courage, Rowman, Lanham, MD, 1998.

[16] Goolam, M. (2014) improving the Quality of Engineering Education in Sub-Saharan Africa. Retrieved from: http://www.gedcouncil.org/sites/default/files/content/G Mohamedbhai,Report\%20on\%20Engg\%20Education\% 20Version\%202_0.pdf

[17] Grusec, J.E., Hastings, P. (2007). Handbook of Socialization, Guilford, New York, 2007.

[18] Harvard Graduate School of Education (2016). Retrieved from: https://www.gse.harvard.edu /news/16/04/engineering-personalized-learning-storysummit-schools-and-facebook.

[19] Hamad, A., Al-Zoubi, A. Integrating 'Learning style' Information into Personalized e-learning System. Retrieved from: https://www.researchgate.net/profile/Abdallah_AlZoubi2/publication/268373931_Integrating_Learning style'_Information_into_Personalized_e_learning_System/links/54cf5fac0cf29ca810fdeaf2.pdf
[20] Hawthorne, F., Oberti, R., Harlow, G., Maresch, W., Martin, F., Schumacher, J., Welch, M. (2012). IMA report: Nomenclature of the amphibole supergroup. Retrieved from: https://www.researchgate.net /publication/236893556_IMA_report_Nomenclature_of _the_amphibole_supergroup

[21] Internet Geography. (2020) What are the environmental impacts of economic development in Nigeria? From: https://www.internetgeography.net/topics/what-are-theenvironmental-impacts-of-economic-development-innigeria/

[22] Kigali. The economist. (Aug 2019) Tertiary education in Africa: A booming population is putting strain on Africa's universities. Retrieved from: https://www.economist.com/middle-east-andafrica/2019/08/10/a-booming-population-is-puttingstrain-on-africas-universities.

[23] Kunnath, M (2019). Personalizing Course Design, Build and Delivery Using PLErify. Retrieved from: https://www.intechopen.com/books/new-innovationsin-engineering-education-and-navalengineering/personalizing-course-design-build-anddelivery-using-plerify

[24] Lawless, J. (2005) Parametric Models in Survival Analysis. Retrieved from: https://onlinelibrary .wiley.com/doi/abs/10.1002/0470011815.b2a11056

[25] MDPI (2019). Special Issue "Towards Excellence in Engineering Education". Retrieved from: https://www.mdpi.com/journal/education/special_issue s/Towards_Excellence_in_Engineering_Education

[26] Mistree, F., Panchal, J. H., Schaefer, D., Allen, J. K., Haroon, S., and Siddique, Z. (2014). Personalized Engineering Education for the 21st Century. Retrieved from:

https://www.researchgate.net/profile/Farrokh_Mistree/p ublication/272826574_Personalized_Engineering_Educ ation_for_the_Twenty-

First_Century/links/54f26cac0cf2f9e34f03fdfc/Persona lized-Engineering-Education-for-the-Twenty-FirstCentury.pdf?origin=publication_detail

[27] Mukeredzi, T (2019) African vice-chancellors agree to review STEM curricula.

retrieved from: https://www.universityworldnews.com /post-mobile.php?story=20191125124727355

[28] Ndung'u, N., Signé, L. (2020). The Fourth Industrial Revolution and digitization will transform Africa into a global powerhouse. Retrieved from: https://www.brookings.edu/research/the-fourthindustrial-revolution-and-digitization-will-transformafrica-into-a-global-powerhouse/

[29] Nordea (2020) Nigeria: Economic and Political Overview. From: https://www.nordeatrade.com/en 
International Journal of Engineering Research and Technology. ISSN 0974-3154, Volume 13, Number 9 (2020), pp. 2429-2436

(C) International Research Publication House. https://dx.doi.org/10.37624/IJERT/13.9.2020.2429-2436

/explore-new-market/nigeria/economical-context

[30] Onuegbu, C (2020).Will Engineering Survive the 4th Industrial Revolution? Retrieved from:

[31] https://medium.com/@collinsonuegbu/willengineering-survive-the-4th-industrial-revolution$5 \mathrm{a} 644 \mathrm{a} 7 \mathrm{df} 5 \mathrm{~d} 7$

[32] Gilbert Nganga , "Survey Finds Most East Africa Graduates 'Half-Baked', University World News, 2014 Global Edition

[33] Royal Academy of Engineering, Engineers for Africa: Identifying Engineering Capacity Needs in Sub-Saharan Africa (Oct.). 2012 Summary report

[34] Shizha, E. (2014). Rethinking Contemporary SubSaharan African School Knowledge: Restoring the Indigenous African Cultures. Retrieved from: http://infonomics-society.org/wpcontent/uploads/ijcdse/published-papers/special-issuevolume-4-2014/Rethinking-Contemporary-SubSaharan-African-School-Knowledge.pdf

[35] Sheikheldin, G., Nyichomba, B. (2019). Engineering education, development and growth in Africa Retrieved from: https://www.researchgate.net/publication /336483576_Engineering_education_development_and _growth_in_Africa/fulltext/5e68250c4585153fb3d5d17 4/Engineering-education-development-and-growth-inAfrica.pdf?origin=publication_detail

[36] The World Bank (2004). Improving the Quality of Engineering Education and Training in Africa. Retrieved from: http://documents1.worldbank.org/curated/en/77383146 8007776683/pdf/860620BRI0WB0H00Box382147B00 PUBLIC0.pdf

[37] Uwaifo, V.O. (2009). Technical education and its challenges in Nigeria in the 21st Century. Retrieved from: http://www.academicjournals.org/app/webroot /article/article1381821563_Uwaifo.pdf

[38] Zeiteh, L. (2002). Using an Active Cooperative Learning Approach to Teaching Technical Writing to Malaysian Undergraduate Engineering Students. Retrieved from: https://www.google.com/url?q= https://www.ijser.org/paper/A-Functional-Curriculumfor-Engineering-Education-in-NigerianUniversities.html\&sa=U\&ved=2ahUKEwi89pzYxLqAhVOsaQKHTU-CWAQFjAIegQIBxAB\&us g=AOvVaw0UAyqhh00z590r--RrZ18k 